\title{
Africa's Youth Unemployment Challenge and the Pursuit of Soft Skills Development by University Students
}

\author{
Joseph Kweku Assan ${ }^{1} \&$ Violette Hilda Nalutaaya ${ }^{2}$ \\ ${ }^{1}$ Joseph K. Assan, Centre for Global Development and Sustainability, Sustainable International Development Program, \\ Heller School for Social Policy and Management, Brandeis University, USA. \\ ${ }^{2}$ Farmerline Ltd., No 7.Sapele Loop, Kokomlemle, Accra, Ghana. \\ Correspondence: Joseph K. Assan, PhD, Centre for Global Development and Sustainability, Sustainable International \\ Development Program, Heller School for Social Policy and Management, Brandeis University, MS 035, Waltham, MA \\ 02454, USA. Email: joeassan @ brandeis.edu
}

Received: April 8, 2018 Accepted: April 23, 2018 Online Published: June 12, 2018

doi:10.5539/res.v10n3p58 URL: https://doi.org/10.5539/res.v10n3p58

\begin{abstract}
This paper seeks to address the growing challenge of youth employment in Kenya. The study explores how the provision and acquisition of soft skills by university students influence their employability in the current labour market in Kenya. The objective of the paper is to examine the current training programs in soft skills development being offered to university students and the extent to which they enhance the ability of the participants to obtain employment. We use a case study approach to ascertain the opportunities provided by the Employment Training Program which offers mentoring and coaching to young people in key soft and employment skills as they transition from tertiary institutions into the workforce. The paper triangulates quantitative and qualitative methodologies that draw on a pre-training survey, key informant interviews, a post training survey and focus group discussions to inform the study. The research shows that addressing the information gap for job opportunities can help reduce youth unemployment. The development of entrepreneurship, interpersonal skills, public relations and online jobs search skills are amongst the observed training gaps. The findings of the study further indicate that employers are interested in young people who are consistent, reliable, have good communication and presentation skills as well as realistic career expectations. The study concludes that whilst several students seem keen on obtaining soft skills, some are unable to capitalize on the acquisition of such skills to enhance their employment prospects. The paper recommends incorporating employability programs into the Kenyan educational curriculum at the secondary and tertiary levels to address the vicious cycle of unemployment.
\end{abstract}

Keywords: Employment training programs, Kenya, Livelihoods, Soft skills, Tertiary Education Youth Employment

\section{Introduction}

According to the United Nations Deputy Secretary-General, Amina J. Mohammed, Africa has the fastest growing youth population in the world, with 60 per cent of its population under 24 years (UN, 2017). She argues that harnessing their capability entails better investments in education, to ensure a healthy labour force that is capable of meeting the progressively robust demands of our current globalized markets. This, according to her, could subsequently contribute to rapid growth in consumption by households and businesses. The OECD (2018) argues that to ensure the effective contribution of economically active youth to the global economy, there should be careful approaches regarding the transition from school to work. This, in their opinion will help curb of the current global youth unemployment crisis.

The International Labour Organisation (2016) suggests that youth (15-24 years) unemployment outlook for the major economies of the region remains quite mixed, ranging from 1.8\% in Benin to 54.4\% in South Africa. ILOSTAT (2017) further illustrates this variation by indicating that whilst for example in South Africa, the regions strongest economy, more than half of all economically active youth remained unemployed in 2017, representing the highest youth unemployment rate in the sub Saharan African region, the rate for Tanzania is (5.4\%), Nigeria (8.5\%), Central African Republic (10.8\%), Ghana (11.5\%), Mozambique (41.7\%), and Namibia (43.8\%).

ILO (2016) further reveals that working poverty rates among youth in sub-Saharan Africa was nearly 70 per cent in 2016, translating into 64.4 million working youth living in extreme or moderate poverty (less than $\$ 3.10$ per day). According to the same source, the amount of poor employed youth has unfortunately risen by as much as 80 per cent for the past 25 years. 
Nonetheless, like many sub Saharan African countries, Kenya is experiencing a youth bulge with over $43 \%$ of the population under the age of 15 (CMI, 2015) and 80\% of its population under 35 years (British Council, 2015). Reminiscent of South Africa, and in spite of being the largest economy in the East Africa region, Kenya is faced with the issue of youth unemployment, with insufficient jobs to meet the employment needs of its youth (Kinuthia, 2017).

Kenya's youth bulge creates an employable population of 24 million, with an unemployment rate of 20\% (Sunday, 2017). Nevertheless, it is estimated that $62 \%$ of youth have education below the secondary level, hence, most youth in Kenya do not seem to have the education/training and skills to match the few job openings available (Brookings Institute, 2014). In addition, the unemployment rate in urban centers is markedly higher than that of rural areas. The Brookings Institute (2014) reports that the urban youth unemployment rate is $19.9 \%$ compared to the rural $11 \%$. According to the British Council, Kenya's universities produce about 50,000 university graduates every year, which significantly far exceeds the employment capacity of its formal sector (British Council, 2015).

Whilst entrepreneurship and training vocational programs were considered as the solution to this problem a few decades ago, these efforts have not translated into employability. Encouraging startups and innovation in business is an important aspect to jump start entrepreneurship, yet there is a lack of capital investment and skills for youth to be successful in these ventures. Several young people have subsequently enrolled in tertiary institutions with the hope of overcoming this vicious cycle. Such decisions have consequently created another problem, which is how to transition university students to job seekers, job creators and or employed.

Inadequate employable skills within the tertiary educational curricula and teaching programs are considered as serious barriers which seem to precipitate the observed patterns of unemployment and underemployment amongst university and college graduates in Kenya. The need for additional employability skills based curriculum in tertiary level educational programs accompanied by policies that address this gap is perceived as a potential solution. An international research conducted in 42 countries revealed that $19 \%$ of employers found it difficult to fill specific positions because of the lack of soft skills as an area of competency (Manpower group, 2014). Kubes et al (2004) contend that the progression of competency based approach in human resources management and administration has led to an emphasis on skill levels of workers in addition to formal education qualifications in the employment process. They argue that job seekers with soft skills, life skills, interpersonal skills and employable skills are considered to be better positioned to navigate the job market compared to those without. According to UNESCO (2012), employers want assurances that young job seekers have foundational skills and can deploy their knowledge to solve problems. UNESCO acknowledges that these skills are unfortunately not offered by several of our tertiary educational institutions.

This paper will examine the extent to which the acquisition of soft skills (employable skills) through tertiary educational programs provide adequate training which enable university students to find employment or develop startups upon graduation. The study seeks to understand the nature and impact of soft skills development programs and the extent to which they prepare students to be confident enough to find or create employment in Kenya. The rest of the paper is structured as follows: the next section focuses on the theoretical debates associated with the soft skills, employment and unemployment. Section Three discusses the background of the paper and the methodologies employed by the study. The subsequent sections discusses the results of survey and field work and concludes with some policy recommendations.

\section{Literature Review}

\subsection{Employable Skills: Contemporary Notions for Youth Employment}

The Cognitive Capitalism, which is characterized by the Knowledge Economy is perceived to be the driver of employment and entrepreneurship of our contemporary times. Yamamoto (2017, p. 2) argues that "the generation of knowledge and its spatial diffusion through the learning and network processes are the basic features of contemporary economy on which the new notion of employability is defined by". The conception of employability and employable skills seem to dominate our current discourse in political economy. It might however be defined differently depending on the industry. Nevertheless, employability has been clustered to show specific characters sought by employers. The development of generic skills for prospective career or employment opportunities has had its roots focused on the concepts of employability and transferability from our understanding of industry and the public sector (Mayer Committee, 1992; Australian Industry Group, 2000). Hollingsworth (1997) posited that the changing nature of the labour market is impacting on the training of skilled workers. This is because several organisations now expect their prospective employees to have obtained the requisite skills needed for advertised roles elsewhere.

In view of such shifts in the workplace, globalization, new technologies and increased migration, the expectations of employers from university graduates has equally increased. Graduates are required to have skills that are relevant to the modern-day workplace (Weil and Oded, 1999). Moreover, with Africa being a young continent with respect its demography, the need to train young people in employable skills with emphasis on soft skills has become more important today than ever. Employers expect young people to think outside the box, work in teams, communicate effectively and 
build their entrepreneurship muscle.

A lot of emphasis is currently being placed on what is now often referred to as soft skills. This is defined as the "interpersonal, human, people or behavioral skills needed to apply technical skills in the workplace" (De Villiers, $2010, \mathrm{p}$. 2). Soft skills visualize a social setting at the workplace, making a calling for an interconnected work environment that has interaction of teams. Alex (2008) provides a more a comprehensive definition of soft skills as "know yourself and know the world". He recognizes social, thinking and negotiating skills as being most critical for those entering the labor market. He highlights examples to include self-discovery, positive attitude, forming values, improving perception, career planning, emailing, body language, team building, group discussion, social etiquette and manners, resume writing, interview skills, and stress management and critical thinking.

\subsection{Theoretical Conceptualization of Soft Skills}

The flixibilization of the labour market and the inflation of educational credentials is considered as posing various challenges to young graduates seeking employment. Studies by the Harvard Business School suggest that employers are continually raising the bar as far as the credentials of their employees are concerned (Fuller and Raman, 2017). They argue that three out of five employers rejected middle level skill personnel in favour of college graduates. As a result, college graduates are increasingly being expected to possess the requisite soft skills to fit into multiple key positions requiring flexible skills. Again, Fuller and Raman (2017) revealed that "half of employers report paying higher compensation to recent college graduates than non-degree workers in the same job. Of those employers, 68 percent pay recent college graduates salaries 11 to 30 percent higher than middle-skills workers with experience”. Soft skills, as a concept has been incorporated into frameworks for employment and has also been used to model the work skills for the $21^{\text {st }}$ Century. Today's employment is perceived as characterized by people with diverse skills working within smaller teams (World Bank, 2012).

Consequently, every individual worker is expected to have the skills and capacity required to multitask. The existing literature largely consider soft skills in terms of work and excelling at a job but also for survival and sustainability of participants in the labor market (Heckman \& Kautz, 2012). These skills have been termed as employability skills, transferable skills, generic skills and so many other terms that are identical to each other. Soft skills are therefore referred to as enablers for excellence at work (Ramesh, 2010). It is important to note that employability skills include two categories of skills: technical and soft skills (Omar, Bakar, \& Rashid, 2012; Robles, 2012). The ongoing debate on the relevance of these skills is whether they complement or rival each other and whether soft skills can be learned at any age and taught through a curriculum in a higher educational institution.

The relevance of soft skills has increased in significance as seen from different empirical studies (Heckman \& Kautz, 2012; Aring 2012). According to Borghans et al. (2006) there was an increase in tasks that required people skills from 1970 to 2002. Other schools of thought show the growth of jobs was concentrated in those areas that required the blend of both soft and technical skills (Weinberger, 2011). For the jobs that required either technical or soft skills, there was stable growth from 1977 to 2010. These findings agree with Bacolod and Blum (2008), who show how these skills support each other with a statistically significant relationship between cognitive skills and soft skills.

The Kenyan Labor market is characterized by services which require strong soft skills. According to Noon et al. (2013), there is an increase in the demand for soft skills because of the growth in the service sector. There is continued reference to the role of soft skills in increasing productivity at work, although there is no agreement to which specific set of skills are key. Moore et al, (2015), provide for a presentation and understanding of key soft skills for workforce competence from their research. The benchmarks used include the extensiveness, magnitude and appropriate inclusiveness of the skill. This includes both informal and formal employment over a wide range of sectors and regions and whether the skill is also trainable among youth ages 15-29.

Goleman (1998, p.4), associated soft skills with emotional intelligence. He argued that emotional intelligence is concomitant to employability when the notion of employment is inherently being linked to the acquisition of "portable skills" which is sometimes referred to with a range of synonyms including "character, personality, competence and soft skills". Nevertheless, the conceptualization of emotional intelligence is also considered contentious as it seems to conjure diverse viewpoints and definitions. The emphasis on emotional intelligence is in contrast with other international employability assessment frameworks such as OECD's Program for the International Assessment of Adult Competencies (PIAAC) and the Program for International Student Assessment (PISA) Programs (Martin (2018). Goleman argues that emotional intelligence and soft skills are the qualities that make and keep us employable. Chopra and Kanji (2010) showcase a framework for emotional intelligence based on emotional skills, intrapersonal development, social, economic factors and management excellence. They argue that it is important for one to know how to work with others, acknowledging their strength and how to equally to contribute to the team's aggregate output. According to Sable (2001), the emerging work industry lays emphasis on collaborators, and being able to continuously redefine joint projects across 
disciplinary and geographic frontiers which in turn allows employees to unremittingly judge one another's rectitude and capacity to meet joint expectations. Such diverse expectations require some intellectual sophistication, fluidity and skills to meet expectations.

\subsection{Soft Skills and Graduate (Un)Employability}

Employers are reported to consider the lack of life skills training as a common concern associated with Kenyan High School and College Graduates (Ponge, 2013). There is a general presumption that higher education would produce graduates with critical life skills for employment. Evidence on the ground seems to suggest otherwise. On average, a university graduate in Kenya may take five years to find a job (Omollo, 2015). The transition time to find a job may not only be attributed to a lack of soft skills alone.

Employers are seeking people with skills and therefore the role of training that is expected of employers is also shifting to personal initiative by the young people. Young Kenyans need to prove their work ethic by becoming more dependable and reliable since most of the jobs require experience (Danner, Makau, Nebe, 2016). Smith et al. (2016) call for an educated graduate who still holds cultural values and can display the same at the work place; these go a long way in work relations and negotiations. This problem is not unique to Kenya. Employer surveys in other African countries highlight basic and soft skills gap and entrepreneurship gap in Ghana, Senegal, Egypt, Namibia and Botswana (Aring, 2012). These factors affect graduate employability as employers seem to prefer employees who demonstrate possession of soft skills.

It is argued that at the interview stage, employers will always look out for candidates who show critical thinking, ability to solve problems at the workplace among others (Green, Graybeal, \& Madison, 2011). Green et al. (2011) established that employers appreciated candidates who are strong in skills. These include social, communication, higher order thinking skills, intrapersonal skills and positive self-concept (Lipmann, Ryberg, Carney \& Moore, 2015). Employees are expected to understand key soft skills as these skills are considered to increase the outcomes at the different employment places regardless of the industry or vocation. Soft skills have been referred to as skills for the $21^{\text {st }}$ century. The $21^{\text {st }}$ Century tasks are branded as requiring soft skills such as critical thinking and communication duties that involve staff locally and internationally. There is a decline in the population that is involved in monotonous work (Levy \& Murnane, 2004). This calls for a labour market with the willingness and ability to innovate and learn. USAID (2016) Positive Youth Development (PYD) tool kit provides a template for developing the training needed to address the growing training gap in soft skills as youth transition from educational institutions into the workforce of their respective countries. It is important for national and local level initiatives that can adapt such programs as part of the curriculum to address local concerns regarding the relationship between educational institutions and employment.

\section{Research Background and Methodology}

\subsection{Government Employment Policies and Employable Skills}

The country has seen the articulation and implementation of policies that seek to address the employment in Kenya. Government was seen to be responsible for economic growth, employment creation, setting up of industries, regulating investment, wages, planning education, including technical and vocational training. An initial step is the increase in wages and the embracing of Kenyanisation policies soon after independence (Republic of Kenya, 1964). More recently, the government formulated a five-year strategy to raise growth and development through the implementation of the Economic Recovery Strategy for Wealth and Employment Creation 2003-2007. This provided streams of opportunity for employment and created other synergies for gaining income for the people.

In spite of these interventions, the creation of adequate, productive and sustainable employment continues to be the greatest challenge in Kenya. The youth employment challenge has particularly been aptly recognized in the country's long-term development blueprint. These include the following: Vision 2030, the Medium Term Plan (2008-2012), and Labor, Youth and Human Resource Development Sector Plan (2008-2012). Hence, the need to promote youth employment in Kenya through the training of resilient life skills cannot be over emphasized.

Kenya's youth are faced with several employment challenges. These include: lack of employability, limited employment creation or absorptive capacity of the economy, weak entrepreneurship culture and unequal opportunities, mismatch of employment skills and the lack of the key skills (both technical and soft skills). As Kenya works towards becoming a middle income economy through implementing Vision 2030, it is imperative that policy makers and planners in the Ministry of Education develop curriculum that will facilitate employability of graduates after their university and college education by preparing students for the 21 st century employment and business opportunities. 


\subsection{Case Study: Building a Sustainable Youth Employment Program}

This study sought to examine the opportunities that lie in mentoring and coaching young people in key life and employment skills as they transition from school into internships or full-time employment, using a case study approach. An international NGO is working with universities in Kenya by providing studentships, mentoring and employability skills training to talented but underprivileged students in Kenya through what is called the Employment Training Program. The Employment Training Program believes that access to education and pathways to employment are the greatest barriers for young people trying to break through the cycle of poverty in Kenya. The program aims at providing training opportunities to empower students to become community leaders and successful professionals and thereby helping to achieve Kenya's national development and poverty reduction policy framework know as Vision 2030. This will be achieved through a continuous training of the Employment Training Program students on various aspects of soft skills throughout their eight year studentship program. This program is meant to serve as a bridge to other employment programs.

This study sought to examine the opportunities that lie in mentoring and coaching young people in key life and employment skills as they transition from school into internships or full-time employment. Having worked with school going youths, the Employment Training Program is currently working on an employability program aimed at transitioning the first group of graduates who joined its studentship program in 2013. The organization is currently developing a networking program that will be delivered through relevant internships and professional mentorship of the graduates.

It is expected that the transition of disadvantaged youth into a formal employment environment will not only bring opportunities but also pose challenges in terms of adjusting to the new norms and expectations. The Employment Training Program will assist the students within the employability bracket in securing jobs through assistance with certification, mentoring, continuous training and internship placement support so that they can make a successful transition into the workplace. Those who will be earmarked for entrepreneurship shall be introduced to credit facilities to enable them to raise sufficient capital for their enterprises. The program will also put in place a robust mentoring and placement support system to provide continuous-training follow-up to the participants systematically and effectively.

\subsubsection{The Nature and Structure of the Training Program}

According to the Bridge to Employment Program (2016) program implementation document provided by the director of the International NGO, the program aims at developing highly-employable, productive members of the community who will ultimately become agents of change to transform their communities. The vision is to build the employability capacity of the participants by exposing its students to skills development opportunities by building their leadership, competences and experience (through Community Service, online work, project work, internship, mentoring, entrepreneurship).

The skills development and mentoring program expect participants to build their practical skills in leadership, critical thinking, problem solving, communication and networking over an 8 and half years period. The program recruits students from Form one (Middle school) and university graduates with a diploma or degree.

The bridge program comprises of four levels or phases in this paper:

Phase 1: Bridge to Success - this is a 4 year program developing life skills, community service culture and leadership. It starts from Form 1 to Form 4 (middle school equivalent),

Phase 2: Bridge to College - this is a four month training that targets the students transitioning from high school to college. The training comprises of three months community service, two weeks of computer literacy and career planning training and one week design thinking boot-camp to develop innovation mindset. During this period, the students identify their career of choice, selects the programs that would place them in that career and applies to study the program.

Phase 3: Bridge to Employment - this is a 3-year mentoring and coaching program that guides the students in building their competences and experience through community service, internships and training. This phase of the program provides opportunities for the participants to build their employability capacity, build communities of interest and network with each other and the business community. It blends face-to-face training with online facilitated coaching. There are three boot-camps over the three years during which the students show-case their innovations and creativity.

Phase 4: Transition to Work Phase - this is a one-year Transition to Work Coaching Program that involves both face to face and online coaching in personal reflection, career path planning, work placement and entrepreneurship training. The final stage of the Bridge program serves to coach the participants in career path planning through self-reflection and professional development planning activities. This phase formally starts with a five-day induction and forward planning, eleven months of online coaching and a one-week boot-camp.

To ensure the attainment of program objectives and sustainability of outcomes, the organisation has incorporated a mentoring component which runs throughout the all the phases and sequence of the program. All participants are attached 
to a mentor and in addition, the older students mentor the younger students. Program participants is expected to demonstrate the competences outlined in Table 1 by the end of the training.

Table 1. Expected outcomes and competency indicators

\begin{tabular}{|l|l|}
\hline Soft Skills & Expected Competencies \\
\hline Computer skills & Develop the ability to use tools and programs required for conducting basic office tasks \\
\hline $\begin{array}{l}\text { Entrepreneurial } \\
\text { Leadership }\end{array}$ & $\begin{array}{l}\text { Design an initiative that addresses a real life situation and implement the project and identify } \\
\text { and build a team to implement the initiative }\end{array}$ \\
\hline Branding skills & Define projects output, product and develop marketing/selling strategy \\
\hline Communication & Display capabilities in being able to write and present the project to external agents \\
\hline Self-management & Demonstrate effective time management, plan and assess personal development needs/targets \\
\hline
\end{tabular}

Source: Authors (2018) Construction from program document

In addition, the program actively engages the private sector for employment opportunities and finds innovative ways to mobilize their support as part of their broader Corporate Social Responsibility (CSR) initiatives for talent promotion. The Employment Training Program is expected to serve as a bridge to national networks of entrepreneurs, employers, mentors and service providers which will further provide the young graduates with a platform for networking. This avenue will also provide access to opportunities and resources such as markets for services and products, employment and mentorship opportunities and access to financial services. The networks will serve as an organic support system even after the project has ended.

\subsection{Methodology}

The study purposively sampled students participating the students' employment training program in Nairobi, Kenya. The research employed a mixed method approach involving questionnaire survey and interviews to collect data that the study is based on. The quantitative data was analyzed using simple descriptive statistics. The qualitative data was analyzed manually using themes, quotes and context and in relation to training, educational curriculum of their respective educational institutions and employability. The total population of program participants was 174 . Out of this number, 64 of program participants took part in the survey.

\subsubsection{Self-Reporting}

This was done at the start of the training by sending out a pre-test survey to understand the soft skills gaps of the young people who were part of the program. The participants in this study were from Jomo Kenyatta University (JKUAT), Kenyatta University (KU), University of Nairobi (UON) and Africa Nazarene University (ANU). This method was also used at the end of the training for all the 174 students who were part of the program. This data collection tool was designed and disseminated using Google documents as all the students had internet access. At the end of the training, the investigator randomly sampled some of the students from the study for a focus group discussion. This was done to establish the impact of the training in the short term and provide feedback on their respective experience.

\subsubsection{In-depth Interviews}

The study also randomly sampled and conducted structured interviews with five employers who are currently involved in providing internship programs for University graduates. The employers include Kenya Private Sector Alliance (KEPSA an umbrella organization), Safaricom Limited, Kenya Human Rights Commission (KHRC), Kenya National Human Rights Commission (KNHRC), the Ministry of Youth and Sports (MOYAS) and Carolina for Kibera (CFK). Interviews were administered to ascertain the expectations of employers regarding university and college graduates entering the labor market. 


\section{Results and Discussion}

\subsection{Gender, Age and Educational Level of the Respondents}

This section examines the results from the study and offers key discussion. The study sample consisted of $64 \%$ female and $36 \%$ male respondents. The respondents were between the ages 18 to 27 years with the majority being 20 years old. Further analysis of the data revealed that the mean age is 21.47 years. As per the Kenya Constitution, a youth is described as individuals between the ages 18-35 years. Majority of the respondents (61 percent) were pursuing a university degree. Twenty Eight (28) of the respondents are enrolled in a diploma awarding programs whilst 11 percent of the respondents are high school graduates. However, the high school graduate respondents are individuals who have obtained admission to pursue courses in local colleges. Nevertheless, their participation in the soft skills training program qualified them to participate in the study.

\subsection{Choice of University Course in Relation to Respondents' Dream Job}

The wide spectrum of ambitions shows that the youth in Kenya are indeed aware of the various opportunities available in national job market. This also shows that there is no specific inclination towards specific professions. The general trend points towards training for office jobs.

\subsubsection{Factors that Influence the Selection of Study of Course}

It was observed that there was a correlation between the students' preferred field of study and their dream jobs. When asked about what the major influences of their study choices were, it was noted that most of the respondents chose their current courses based on their passion $(60 \%)$. The analysis also revealed that $22 \%$ of the respondents chose courses based on market trends even though it was not clear how they concluded on the prevailing market trends. Family members also seemed to play an important role in course selection while some just accepted what was offered to them through the admission and placement system as designed by the government through Kenya Universities and Colleges Central Placement Service (KUCCPS).

Table 2. Students Perception of Employability Factors

\begin{tabular}{|l|l|}
\hline Key variables & Responses (\%) \\
\hline University offers soft skills training & Yes (52\%); No (31\%); Not aware/Maybe (17\%) \\
\hline $\begin{array}{l}\text { Factors that influenced students decision } \\
\text { on the choice of university program of } \\
\text { study }\end{array}$ & $\begin{array}{l}\text { Passion/interest (60\%); Based on market trend (22\%); } \\
\text { Based on family advise (8\%); Ease of finding a job in this field (6\%); } \\
\text { KUCCPS selection system (3\%); No particular reason (1\%) }\end{array}$ \\
\hline $\begin{array}{l}\text { Types of Soft Skills offered at } \\
\text { participants respective universities }\end{array}$ & $\begin{array}{l}\text { Communication skills (46\%); Team building (11\%); Internship placement } \\
(11 \%) ; \text { Career service (11\%); CV preparation (9\%); Life skills (7\%); Critical } \\
\text { writing skills (5\%). }\end{array}$ \\
\hline $\begin{array}{l}\text { Confidence in finding ones dream job } \\
\text { after participating in training }\end{array}$ & Very confident (33\%); Confident (61\%); Less/Not confident (6\%) \\
\hline
\end{tabular}

Source: Authors (2018)

\subsubsection{Soft Skills at the University}

The study sought to find out if the universities/colleges do have a soft skills training framework which the students were familiar with and actively participated in to enhance their career aspirations. The results revealed that only 52 percent of the respondents were aware that their institutions had such a program in place. Thirty One percent $(31 \%)$ said that their institutions did not have soft skills training component in their curriculum while 17 percent of the respondents were not aware if this existed in their university. Given that all the respondents were presumed to be studying in the public education institutions, this finding raises a few questions and concerns. This is because, although the institutions exercise autonomy in their functions, the regulator does play a major role in course approvals, hence, variations in the course content ought not to reflect significant shifts with respect to soft skills training or development. Upon further analysis, the study observed that this was as a result of a non-structured soft skills curriculum which some of the respondents were not aware is on offer at their respective universities. Given that the respondents are participants of a structured soft skills training program, the results seem to reflect a key disconnect across the universities/colleges curricula regarding the integration of soft skills into their respective academic programs. 


\subsubsection{Improvement of Students' Confidence Level}

The research sought to establish whether there was improvement in the confidence levels among the respondents across various aspects of their soft skills training over the previous six months. The results, as illustrated in Figure 1 shows that the majority of the respondents had very high confidence levels in two areas of skills: email communication and team work whilst a small majority seem to profess to be confident is several aspects of soft skills development. It could also be deduced that in spite of the training programs, most of the students are not confident in several of the soft skills that they were expected to acquire. This might imply that the period of training perhaps needed to be extended to allow the students to achieve better results. However, the results show a positive improvement on seven out of ten skills which suggests improvement.

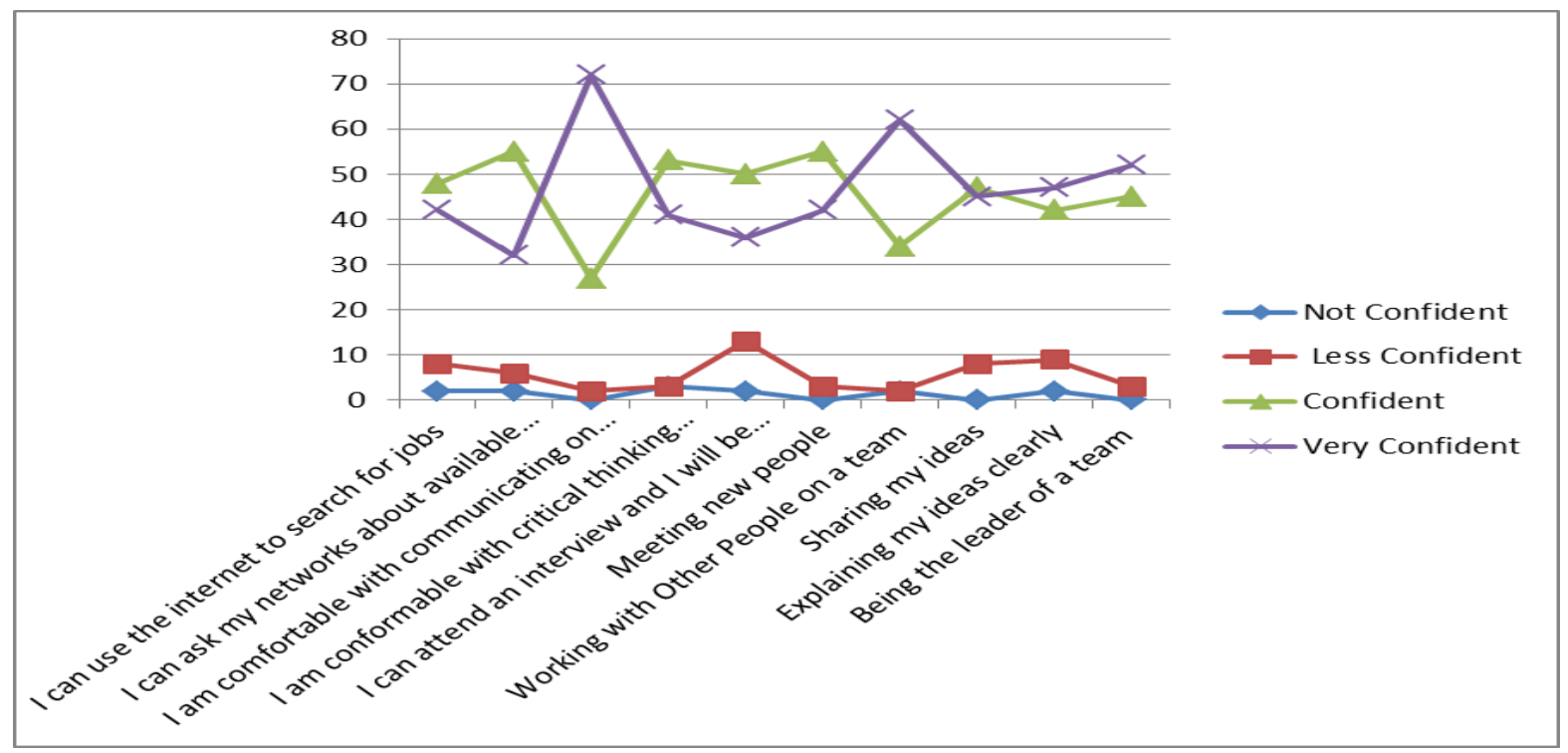

Figure 1. Confidence Levels of the Youth after being Part of Skills Training Program

Source: Authors (2018)

The study further sought to understand the soft skills programs offered at the universities and their perceived impact towards enhancing employment. When asked about any missing soft skills that they considered they needed to be able to pursue meaningful employment, the responses show that the majority of the respondents are satisfied with the current skills integrated in their studies. A few students however mentioned some technical skills related to their studies such as ICT, accounting packages, microscopy, data analysis, cyber security among others. Also, less than $1 \%$ of the study sample mentioned interview skills, emotional intelligence and problem-solving skills. Apparently, these responses could be attributed to respondents who are yet to start their college studies. Over $95 \%$ of the respondents were confident that the soft skills that are currently being taught are sufficient to enable them to gain meaningful employment.

When asked to rate their confidence levels in getting a dream job or starting their own businesses, $61 \%$ of the respondents recorded average confidence levels whilst $33 \%$ percent were very confident. Only $6 \%$ felt less confident. Those whose confidence levels had not improved by the program cited the following as factors/skills that they feel might boost their confidence levels in getting their dream jobs and or starting their own businesses: being provided with a comprehensive list of all the possible jobs relating to their area of study; accreditation/licensing of some under graduate programs such as a diploma in community health as it is done with degree programs in public health; exposure to accounting programs and software packages. It is striking to note that students' consider the lack of appropriate accreditation of some diploma and degree programs as having a negative impact on their prospects of obtaining employment after pursuing such programs. The laxity associated with such bureaucratic processes means that some employers do not recognize some programs which then translates into low recruitment in some courses, both at the diploma and degree levels. 


\subsection{Awareness of Employment Opportunities and Required Skills}

When asked about their awareness of employment opportunities and skills required to secure such forms of employment, $52 \%$ of the respondents answered in the affirmative, with $42 \%$, saying that they did not know about the existing opportunities. A notable observation is that most of the female respondents were able to point out specific gender based affirmative employment opportunities and programs like the Safaricom women in technology internship program. The male respondents however, did not seem to have such knowledge or awareness. It is therefore evident that despite gender disparities in most fields like engineering, women are more informed of the existence gender based employment opportunities. This could be alluded to the many affirmative action measures being taken by various organizations in the country including the Kenya government in promoting and empowering women in the workplace. It is hoped that this observation could translate into a gradual increase in the participation of women within Kenyans labour market. In fact, when asked about the gender related challenges in finding employment, some of the male counterparts complained about the extensive emphasis on women and the girl child. This is quite surprising given that women in general tend to have limited opportunities compared to men in their pursuit of employment opportunities.

When asked about the most important skills required for their dream jobs, the respondents gave various responses with communication being the most noted skill. Most of the respondents are inclined towards team work and problem-solving skills as key in their prospective jobs. This can be interpreted to mean that the respondents consider communication as the hall mark of success in their future jobs. This means that tertiary institutions will have to invest in the development of curriculum that will support students in the development of such skills.

\subsection{Perspectives of Employers from Interviews}

The study first sought to learn about how the sampled organizations initiate such internship programs, given the pressure on employers to undertake such human resource endeavor with little or no resources. The Deputy Executive Director of Kenya Human Rights Commission explained that they take in graduate 20 interns every year. He further explained that their choice of students and disciplinary backgrounds of the selected students is based on the organizations human resource need. He indicated that the interns go through an interview process and are put on a one month probationary period. With respect to soft skills required at entry level, he intimated that:

"we look at individual's ability to be assertive as well as exhibiting critical thinking skills. I am proud to say that whoever has been part of our internship program makes a big impact wherever they join other organization after their internship period, because of the quality mentorship they receive here as well as the amount of exposure to the work we do".

The interviews with employers currently involved in providing internship opportunities and mentorship training to some selected participants of the program regarding their performance at work in general, generated diverse perspectives. We perceive these observations to be particularly pertinent to the development of sustainable skills training programs for current and prospective graduates. Two common concerns identified by all the employers is that many of the student interns do not have the ability to keep to time, especially with respect to punctuality and staying occupied during the full working day. Whilst the lack of punctuality could be attributed to several factors including the poor public transport system that generally causes employees arrive late to work, it is important for internship programs to inculcate such disciplines into the preparatory phase of their training curriculum. However, an intern's inability to stay focused and engaged during the hours of a full working day is a critical concern, to say the least. Given that these are university students and graduates who are expected to be independent young adults and have gone through rigorous undergraduate programs, are unable to keep stay engaged during a normally working day which runs from 9am to $5 \mathrm{pm}$, is disturbing. The head of the Talent Acquisition Department at Safaricom Ltd. Kenya explained by saying that:

"time keeping for some of the interns, is a major professional gap. Also being productive through the working day has been a significant gap or a challenge for some of the interns, as some struggle to concentrate during a full working day of 8 hours. They are young and seem find it hard to concentrate and work all day".

Although no particular reasons could be attributed to this pattern since it varies from one individual to the other, it is imperative that graduate interns are offered some tutorials on what to expect in the progressive work environment and also learn about how to productively engage and utilize their working day. Nevertheless, our discussion with some of the interns revealed that many of them easily get bored with the monotony of the work environment. Others indicated that they struggle during the day because they go to bed late, whilst others explained that they take part-time professional accounting and management classes in the evenings after work and as a result get home late and are not able to get enough overnight rest. These factors may have to be taken into serious consideration when providing mentoring and professional shadowing support for such young people and provide them with strategies to enable to develop the needed resilience and or discipline that will allow them to be perform well at work during the day.

In response to these concerns, a senior staff of the Kenya Private Sector Alliance Foundation (KEPSA), argued that these 
life skills are very foundational to one's professional life but are not necessary offered at the university. She indicated that such soft skills are absolutely essential. In her analysis of these concerns, she cited an example of what her organization did for a group on interns as part of a training program she led. She said:

"we recently finished a program that involved life skills training and matching the young interns to internship programs. Some of the skills we trained them included team work, being innovative and communication skills".

Such skills development training offers the interns the ability to learn how to be creative at work, employ their innovative skills in dealing with their respective assigned tasks and learn to communicate any difficulties and challenges that they may encounter. "We sometimes assume these attitudes and abilities are natural skills sets, but not everyone is gifted with such abilities".

Following these observations, we were quite determined to understand how organizations are able to transform, as it were, interns and help them to cultivate and acquire skills that they may not be naturally endowed with. A senior staff at the Human Resources department of the Kenya National Human Rights Commission explained citing a current example of the mentoring work she is engage in which involves two interns. She illustrated this process with the following example:

"I am currently working with two young graduates. I generally listen to them and offer them mentoring supporting and coaching on professional areas that they wish to develop skills in. They are very eager to learn so much from me. One of the key things has been mentoring them in the role of interpersonal communication and being reliable in executing their professional responsibilities and duties".

It is evident that mentoring young graduates require a certain level of dedication and experience. The mentor will also have to be willing and ready to help channel the energy and enthusiasm of the interns in the right direction and be prepared to listen to their concern by empowering them to speak up. These efforts are obviously time consuming and require additional levels of dedication and professionalism that mentors will have to possess or be trained on to enable play their roles effectively. Our interviews with some of the staff of the other participating organisation revealed that having a good mentor is not a guaranteed or clear cut expectation whilst developing or finding a determined and dedicated intern is also a process that requires nurturing and motivation. The process seem to require work on both ends on the coin. Another employer who prefers to remain anonymous expressed her concerns which was also resonated by other employers in the sample regarding the unrealistic expectation that some interns have of the work place and what employers are able and not able to do for their employees. Some of these relates to salaries, allowances, benefits and promotions etc. These basically suggest that it is important for interns and young graduates to have their employment expectations and ambitions in the reality of the labour laws and also live up to what is expected of them.

\subsection{Discussion}

The findings reveal that most of the university/college students in Kenya do understand and appreciate the value of soft skills in enhancing their employment prospects. It can also be revealed that most universities/colleges do have an integrated approach to the life skills in their programs. A key concern though, relates to the clarity of these skills to the students and their intended impact. It is hard to theoretically measure the impact of soft skills in an exam set up without due emphasis on the practical aspect of the same. It is for this reason that some of the respondents admittedly are oblivious of the existence of these skills in their studies. Some of the skills like communication and critical thinking are delivered as stand-alone university courses to all the students within the institutions without direct application to any specific subject or professional or career field. Students are therefore not able to make the needed application which then affects their confidence in exhibiting such skills in the professional environment.

The concept of employment in Kenya seems to turn a blind eye to entrepreneurship. Currently, the world seems devoid of meaningful social enterprises that are built on the basis of creativity and innovation. While the study did not specifically test this concept, there was little, if any mention of the concept among the respondents. Employment for many of the students in our sample seem to connote a graduate getting hired and being given specific routine tasks to perform rather than the graduates using their education to set up enterprises to process services or expertise that the society needs.

Nevertheless, while communication is ranked by the respondents as the most significant soft skill, there is little evidence from the results that the respondents can contextualize the skills in different modes of communication and how specifically it would enhance their employment prospects. For instance, many of our respondents said that they are confident in using emails for job applications with little or no reference to verbal or oral communication during interviews as well as communication skills that is needed in the work place.

The manufacturing sector is particularly hard hit with graduates entering the job force without the skills that make them attractive to this sector (Okoth, 2017). Such a burden is considered to shift the skills and capacity development burden to industry, which could possibly limit the number of prospective graduates that could be hired. Nonetheless, with the appropriate investment in education and skills based industry training, graduates could obtain the required essential entry 
level skills. The major issues within the skill gap can be summed up in three broad points; 1) issues of access to secondary education, 2) gap between the needs of the labor market and the curriculum offered by tertiary education institutions, 3) lack of job-creation skills, especially amongst university and college graduates.

Finally, there is a lack of emphasis on job creation and entrepreneurship in tertiary institutions and also by the graduates. This is considered to be due to the lack mentoring programs, access to seed capital, as well as the prioritization of job seeking over job creation. An inclusive curriculum which integrates the training of soft skills with entrepreneurship education/development in institutions of higher education will be a useful example. This could be developed through both formal training and extracurricular activities. Such an approach could involve activities within the classroom like projects with industry, consultancy projects, poster sessions and panel discussion sessions with potential employers, internship programs and faculty/students led events that could be designed and delivered through students working groups.

\section{Conclusion and Recommendations}

Sub-Saharan Africa's population is indeed growing faster than other parts of the world (Sommers, 2009). Like other countries within the sub-continent, the way forward in Kenya is in the ability to harness the potential that the youth offer. This potential must be accessed through education and employment. To do this, there must be concerted effort in bridging the skills gap between university graduates and the job market. The gap between available jobs and employable youth must be reduced. This can be accomplished by investment in entrepreneurial opportunities and incentivizing the hiring of youth.

The study suggests that the more soft skills an individual student possesses, the higher their chances of employment and the density of employment connection networks they may have. The findings of our study suggest that the youth in tertiary institutions are receiving some form of soft skills training through the different programs and course work offered at their respective universities. Nevertheless, the study established that only a few soft skills were imparted through the different coursework. We also observed that youth with soft skills were more competitive in pursuing employment opportunities than those without. Colleges and universities therefore need to adopt a more practical approach in the delivery of the soft skills programs with related evaluation models that have objectively measurable indicators. This will provide opportunity for empirical analysis of the impact of such courses as well as reveal remedial measures that need to be put in place.

Further, it might be useful to integrate social entrepreneurship as a soft skills development program in all the college/university programs in Kenya. This is considered crucial given that the current global job environment is more inclined towards innovation that seeks to solve a myriad of social challenges through entrepreneurship. It was noted in our study that most of the respondents have little or no understanding as well as interest in using skills acquisition as a means of setting up their own enterprises but rather seem to expect to find office jobs which are increasingly becoming marginal. Career departments in the universities/colleges could actively and continuously engage with both the students and the job market to give timely and accurate information considering the dynamics of the social needs that can be addressed by prospective student entrepreneurs.

Providing youth opportunities to create jobs and enterprises and livelihoods diversification programs is required for sustainable economic growth considering the sheer size of this population group (Assan, 2008; Assan, 2014). The youth of Kenya need access to seed capital, market support and training in business development. There are current initiatives by the Kenyan government to address this need. The Youth Enterprise Development Fund, established in 2007, has been working to increase economic access and opportunity. According to Vidija (2018) the fund is growing with reports that the fund will disburse 1 billion Shillings $(\$ 9,925,361.00)$ in 2018 compared to the 2017 budget of 352 million $(3,493,727.07)$ $(\$ 1=0.00099$ Shillings). In spite of this growth there is criticism that access continue to be an issue due to stipulated requirements of the fund. Furthermore, there are reports regarding the repayment structure (Okoth et.al., 2013). The fund is an excellent place to continue working through this challenge however there is the ever present need to improve, increase accountability and increase transparency. The government of Kenya could create incentives for local and international businesses to hire university graduates by providing attractive incentives to employers in exchange.

In addition to job creation, the skills gap must be addressed to support the employment of graduates by removing the structures which tend to impede the agency of the youth (Assan, 2008). Whilst access to tertiary education is much higher in urban areas, the acquisition of employable skills continues to be a barrier to employment. The development of educational programs with vocational and skills training components is critical. There must also be cooperation between the private sector and education institutes to ensure that students are being trained in skills that are in demand. Vocational schools that partner with sectors such as the tourism and the manufacturing industry will be able to create a training-to-position pipeline that satisfies the needs of businesses while providing crucial employment. Solutions are available to these issues, however they require a level of engagement and partnership between the private sector and government that does not currently function optimally. The youth are the future, and an economy that creates space for 
this population is imperative not only for growth of the gross domestic product but for a peaceful future.

Furthermore, there is the need to review the Kenya's school curriculum and integrate soft skills training at the early stages of the educational curriculum. This is critical as the concept of soft skills seem to be relatively new within educational institutions in Kenya as institutions do not tend to emphasize such skills until at the tertiary level of education. This view is also supported by the sample of our study. It is imperative that the Ministry of Education develop a more progressive soft skills program relative to the socio-economic needs of the country and the emerging global economy (Assan and Walker, 2018).

It is critical for the institutions and the individuals involved in this process to harness their individual and collective agency to ensure that such changes and initiatives are not only suitable but also sustainable (Giddens, 1984). The creation of awareness programs among parents, guardians and within the wider society regarding employability skills and training, as well as emphasis on the acquisition of these skills, should be a continuous process and a part of the university's social mandate. In this regard, career departments at the universities/colleges ought to actively and systematically engage with both students and potential employers in order to stay informed about contemporary trends and the needs of the labor market.

\section{Acknowledgement}

We would like to thank all the individual participants of our study for their contribution. We would also like to express our sincere appreciation to all the organisations who participated in the study for their time and interest in this project. We are also grateful to the blind reviewers for their comments. We are very grateful to Education for All Children for their resources and support.

\section{References}

Alex, K. (2010). Soft Skills: Know Yourself \& Know the World. S Chand \& Co Ltd: India.

Aring, M. (2015). ASEAN Economic Community 2015: Enhancing competitiveness and employability through skill development. ILO.

Assan, J. K., \& Walker, L. (2018). Enhancing Citizens Capability to Compete Globally: Rwanda's Formal Language and Education Policy and its Implications for Labour Market Development. Journal of Education and Human Development, 7(1), 1-6.

Assan, J. K. (2008). Generational Differences in Internal Migration: Derelict Economies, Exploitative Employment and Livelihood Discontent. International Development Planning Review, 30(4), 377-398. https://doi.org/10.3828/idpr.30.4.4

Borghans, L., Ter Weel, B., \& Weinberg, B. A. (2006). People: Social capital and the labor-market outcomes of underrepresented groups (No. w11985). National Bureau of Economic Research.

British, C. (2015). Universities, Employability and Inclusive Development. British Council. London.

CMI (2015). The situation of youth and children in Kibera [report] Retrieved on $20^{\text {th }}$ May, 2016, from: https://www.cmi.no/publications/file/5527-the-situation-of-youth-and-children-in-kibera.pdf

Chege, J. II. (2016). Life skills. In H. Danner, M. Kerretts-Makau, \& J. M. Nebe (Eds.). Youth Unemployment in Kenya: A Ticking Time Bomb (p. 12). Nairobi: Longhorn Publishers, Ltd.

Chopra, P. K., \& Kanji, G. K. (2010). Emotional intelligence: A catalyst for inspirational leadership and management excellence. Total Quality Management, 21(10), 971-1004.

Curtis, D., \& McKenzie, P. (2001). Employability skills for Australian industry: Literature review and framework development. Melbourne: Australian Council for Educational Research.

Education for All Children. (2016). Bridge to Employment Program, Retrieved from www.educationforallchildren.org

De Villiers, R. (2010). The incorporation of soft skills into accounting curricula: preparing accounting graduates for their unpredictable futures. Meditari Accountancy Research, 18(2), 1-22.

Fuller, J., \& Raman, M. (2017). Dismissed By Degrees, Accenture, Grads of Life, Harvard Business School.

Garcia, M., \& Fares, J. (Eds.). (2008). Youth in Africa's labor market. Washington, DC: The World Bank.

Galor, O., \& David, N. W. (1999). "From Malthusian Stagnation to Modern Growth." American Economic Review, 89(2), 150-154.

Giddens, A. (1984). The Constitution of Society, Cambridge, Polity Press.

Goleman, D. (1998), Working with Emotional Intelligence, Bloomsbury, London 
Green, B. P., Graybeal, P., \& Madison, R. L. (2011). An exploratory study of the effect of professional internships on students' perception of the importance of employment traits. Journal of Education for Business, 86(2), 100-110.

Heckman, J. J., \& Kautz, T. (2012). Hard evidence on soft skills. Labour Economics, 19(4), 451-464.

Hesketh, A. J. (2000). Recruiting an elite? Employers' perceptions of graduate education and training. Journal of education and work, 13(3), 245-271.

Hillage, J., \& Pollard, E. (1998). Employability: developing a framework for policy analysis. Institute for Employment Studies Research Brief 85. Department of Employment and Education, UK.

Hollingsworth, J., R. (1997) Institutional Embeddedness of American Capitalism, In Crouch, C. and Streeck, W. Eds. Political Economy of Modern Capitalism: Mapping Convergence and Diversity, Chp. 7, London. Sage.

ILO (2006). "School-to-Work Transition, Evidence from Egypt", ILO- UNFPA - El Zanaty \& Associates.

ILO (2016). "Youth unemployment challenge worsening in Africa", World Employment and Social Outlook 2016: Trends for Youth, ILO Press Release, $24^{\text {th }}$ August 2016. Abuja. Retrieved on $21^{\text {st }}$ May, 2017, from: http://www.ilo.org/addisababa/media-centre/pr/WCMS_514566/lang--en/index.htm

ILOSTAS (2017) Unemployment, youth total (\% of total labor force ages 15-24) (modeled ILO estimate) - Africa, Retrieved on $21^{\text {st }}$ May, 2017 from https://www.indexmundi.com/facts/indicators/SL.UEM.1524.ZS/map/africa

Kinuthia, K. (2017, September 11). Youth unemployment threatens Kenya's role as regional powerhouse. Retrieved on February 09, 2018, from

https://www.businessdailyafrica.com/economy/Youth-unemployment-threatens-Kenya-role-as-regional-powerhous e/3946234-4090902-14p3ugmz/index.html

Kubes, M., Spillerova, D., \& Kurnicky, R. (2004). Competences of Managers - Skills of Excellent Managers. Prague: Grada

Levy, F., \& Murnane, R. J. (2004). Education and the Changing Job Market. Educational leadership, 62(2), 80.

Lippmann, L. H., Ryberg, R., Carney, R., \& Moore, K. A. (2015). Workforce Connections: Key "soft skills" that foster youth workforce success: toward a consensus across fields. Washington, DC: Child Trends.

Manpower Group. (2013). 2013 Talent Shortage Survey Research Results. Milwaukee, WI: Manpower Group.

Moore, K. A., Lippmann, L. H., \& Ryberg, R. (2015). Improving outcome measures other than achievement. AERA (Open), 1(2), 1-25. https://doi.org/10.1177/2332858415579676

Munga, B., \& Onsomu, E. (2016, July 29). State of Youth Unemployment in Kenya. Retrieved on February 09, 2018, from https://www.brookings.edu/blog/africa-in-focus/2014/08/21/state-of-youth-unemployment-in-kenya/

Noon, M., Blyton, P., \& Morrell, K. (2013). The realities of work: Experiencing work and employment in contemporary society. Palgrave Macmillan.

Martin, J. P. (2018). Skills for the $21^{\text {st }}$ Century: Findings and Policy Lessons from the OECD Survey of Adults Skills. OECD Education Working Paper, 166.

Ogbu, O., \& Ikiara, G. (1995). The crisis of urbanization in sub-Saharan Africa. Courier, 149, 52-59.

Okoth, E. (2017, July 04). Skills gap clouds industrial vision. Retrieved on February 09, 2018, from https://www.nation.co.ke/lifestyle/smartcompany/Skills-gap-clouds-industrial-vision/1226-3998806-ew2ik5z/index .html

Omar, M. K., Bakar, A. R., \& Rashid, A. M. (2012). Employability skill acquisition among Malaysian community college students. Journal of Social Sciences, 8(3), 472.

Omolo, J. O. (2012). Youth employment in Kenya: Analysis of labour market and policy interventions.

Ponge, A. (2013). Graduate unemployment and employability in Kenya: transforming university education to cope with market demands and the lessons for Africa. International Journal of Social Science Tomorrow, 2(3), 1-12.

Ramesh, G. (2010). The ACE of soft skills: Attitude, communication and etiquette for success. Pearson Education India.

Robles, M. M. (2012). Executive perceptions of the top 10 soft skills needed in today's workplace. Business Communication Quarterly, 75(4), 453-465.

Sabel, C., F. (201). Diversity, Not Specialization: The Ties that Bind the (New) Industrial District. Paper presented to Complexity and Industrial Clusters: Dynamics and Models in Theory and Practice. A Conference Organized by Fondazione Montedison, Under the Aegis of Accademia Nazionale dei Lincei, Milan, June 19-20th, 2001. 
Smith, J., Odera, D. N., Chege, D., Muigai, E. N., Patnaik, P., Michaels-Strasser, S., \& Dohrn, J. (2016). Identifying the Gaps: An Assessment of Nurses' Training, Competency, and Practice in HIV Care and Treatment in Kenya. Journal of the Association of Nurses in AIDS Care, 27(3), 322-330.

Society for International Development (2013). Exploring Kenya's Inequality [report]. Retrieved from: http://inequalities.sidint.net/kenya/wp-content/uploads/sites/3/2013/10/SID\%20Abridged\%20Small\%20Version\%2 0Final\%20Download\%20Report.pdf

Sommers, M. (2003). War, urbanization and Africa's youth at risk: understanding and addressing future challenges. Basic Education and Policy Support (BEPS) Activity and Creative Associates International. Retrieved from http://www. beps. net/publications/BEPS-Urbanization WarYouthatRisk-. Pdf.

Sommers, M. (2009). Education amidst Conflict: The Youth Challenge. PRAXIS The Fletcher Journal of Human Security, 32.

Sukarieh, M., \& Tannock, S. (2008). In the best interests of youth or neoliberalism? The World Bank and the New Global Youth Empowerment Project. Journal of youth studies, 11(3), 301-312.

Sunday, F. (2017, February 25). Kenya's economy groans under weight of its jobless youth. Retrieved on February 09, 2018, from

https://www.standardmedia.co.ke/business/article/2001230740/kenya-s-economy-groans-under-weight-of-its-joble ss-youth.

UN (2017). Regional and Economic Integration in Africa: How to Effectively Involve Africa's Youth Across the National Borders (18 October 2017), Briefing by Africa's Regional Economic Communities to UN Member States and UN System Entities, Africa Week 2017, United Nations, New York. Retrieved on $4^{\text {th }}$ April, 2018, from:

http://www.un.org/en/africa/osaa/events/2017/africaweek-youth.shtml

Vidija, P. (2018, January 23). Youth Enterprise Fund in plans to loan out Sh1 billion to small businesses this year. Retrieved on February 09, 2018, from

https://www.the-star.co.ke/news/2018/01/23/youth-enterprise-fund-in-plans-to-loan-out-sh1-billion-to-small_c1701 814

Weinberger, C. J. (2011). In search of the glass ceiling: Gender and earnings growth among US College graduates in the 1990s. ILR Review, 64(5), 949-980.

World Bank (2008). The World Bank Annual Report: Year in Review, Access on $25^{\text {th }}$ January 2018, from http://siteresources.worldbank.org/EXTANNREP2K8/Resources/YR00_Year_in_Review_English.pdf

Yamamoto, T. (2017). Cognitive Capitalism and the New Spirit of Capitalism: An attempt at brief comparison. Presentation at European Association for Evolutionary Political Economy 2013 Conference, University of Paris 13. Access on $22^{\text {nd }}$ May, 2018 from: file:///C:/Users/Admin/Downloads/Daigaku64-21.pdf

\section{Copyrights}

Copyright for this article is retained by the author(s), with first publication rights granted to the journal.

This is an open-access article distributed under the terms and conditions of the Creative Commons Attribution license (http://creativecommons.org/licenses/by/4.0/). 